\title{
Pain and musculoskeletal discomfort in physiotherapists of the intensive care unit and ward of a university hospital: a retrospective cohort study
}

\author{
Dor e desconforto musculoesquelético em fisioterapeutas da unidade de terapia intensiva e \\ enfermaria de um hospital universitário: um estudo de coorte retrospectivo
}

Renata Maria Eloi dos Santos ${ }^{1}$, Paula Andreatta Maduro², Tarcísio Fulgêncio Alves da Silva ${ }^{1}$, Francis Trombini-Souza ${ }^{1}$

DOI 10.5935/2595-0118.20180025

\section{ABSTRACT}

BACKGROUND AND OBJECTIVES: Both biomechani$\mathrm{cal}$ and emotional factors may contribute to the development of work-related musculoskeletal disorders in physical therapists working at a hospital, but we still do not know if these professionals present musculoskeletal symptoms related to the sector and working time. The objective of this study was to compare the self-report of pain and musculoskeletal discomfort of the physical therapists working in the intensive care unit and ward of a university hospital and retrospectively evaluate, 12 months of work, self-report of pain and musculoskeletal discomfort of physiotherapists in these sectors.

METHODS: The self-report of pain and the musculoskeletal discomfort of the 18 physical therapists working in this hospital were evaluated by the Nordic Musculoskeletal Questionnaire in the admission period (T0) and after 12 months (T1).

RESULTS: No association was found between the self-report of pain and musculoskeletal discomfort and the working sector of these professionals. However, there was a temporal association between the self-report of pain and musculoskeletal complaints in the intensive care unit sector in the following regions: neck $(\mathrm{p}=0.043)$, shoulders $(\mathrm{p}=0.009)$, upper back $(\mathrm{p}=0.043)$, lower back $(\mathrm{p}=0.043)$ and hip and thigh region $(\mathrm{p}=0.027)$. The second shift of these professionals was not associated with pain and=musculoskeletal discomfort.

CONCLUSION: The self-report of pain and musculoskeletal discomfort of physical therapists of this university hospital, both in the admission period (T0) and after 12 months of work (T1) was not associated with the sector in which they work. However, after 12 months, the physical therapists working in the intensive care unit showed an increase in the amount of self-report of pain and musculoskeletal discomfort.

1. Universidade de Pernambuco Campus Petrolina, Departamento de Fisioterapia, Petrolina, PE, Brasil.

2. Universidade Federal do Vale do São Francisco, Hospital Universitário, Petrolina, PE, Brasil.

Submitted in November 26, 2017

Accepted for publication in April 02, 2018.

Conflict of interests: none - Sponsoring sources: none.

Correspondence to:

Curso de Fisioterapia, Universidade de Pernambuco Campus Petrolina

Rodovia BR 203, km 2, s/n - Vila Eduardo

56328-903 Petrolina, PE, Brasil.

E-mail: francis.trombini@upe.br

(c) Sociedade Brasileira para o Estudo da Dor
Keywords: Intensive care unit, Musculoskeletal disorders, Musculoskeletal symptoms, Pain, Physiotherapy.

\section{RESUMO}

JUSTIFICATIVA E OBJETIVOS: Tanto os fatores biomecânicos quanto emocionais podem contribuir para o surgimento de distúrbios osteomusculares em fisioterapeutas que atuam dentro de um hospital; porém ainda não se sabe se esses profissionais apresentam dor e desconforto musculoesquelético relacionados ao setor e ao tempo de trabalho. Os objetivos deste estudo foram comparar o autorrelato de dor e o desconforto musculoesquelético dos fisioterapeutas da unidade de terapia intensiva e enfermarias e avaliar retrospectivamente, em 12 meses de trabalho, o autorrelato de dor e desconforto musculoesquelético dos fisioterapeutas desses setores.

MÉTODOS: O autorrelato de dor e o desconforto musculoesquelético dos 18 fisioterapeutas que atuam nesse hospital foi avaliado pelo Questionário Nórdico de Sintomas Osteomusculares, no período atual (T1) e comparados retrospectivamente com os dados avaliados no período admissional (T0).

RESULTADOS: Não houve associaçáo entre o autorrelato de dor e o desconforto musculoesquelético e os setores de atuação desses profissionais, porém houve uma associação temporal entre o autorrelato de dor e o desconforto musculoesquelético na unidade de terapia intensiva, nas regiôes de pescoço $(\mathrm{p}=0,043)$, ombros $(\mathrm{p}=0,009)$, parte superior das costas $(\mathrm{p}=0,043)$, parte inferior das costas $(\mathrm{p}=0,043)$ e região de quadril e coxas $(\mathrm{p}=0,027)$. A segunda jornada de trabalho desses fisioterapeutas não se mostrou associada com a dor e o desconforto musculoesquelético.

CONCLUSÃO: O autorrelato de dor e desconforto musculoesquelético de fisioterapeutas desse hospital universitário, tanto no período admissional (T0) quanto após 12 meses de trabalho (T1) não se mostrou associado com o setor de atuação desses profissionais. Depois de 12 meses, os fisioterapeutas da unidade de terapia intensiva apresentaram aumento no autorrelato de dor e desconforto musculoesquelético.

Descritores: Distúrbios musculoesqueléticos, Dor, Fisioterapia, Sintomas osteomusculares, Unidade de terapia intensiva.

\section{INTRODUCTION}

Work-related musculoskeletal disorders (WRMD) are characterized by a chronic-degenerative and psychosocial process. Factors like repetitiveness of movements, mechanical overload 
in the body segments, static muscle work, improper postures for long periods, impact, vibration, cold, physical exertion, organizational and psychosocial factors can give rise to these disorders and their physical symptoms such as pain, edema, paresthesia, joint stiffness, decreased strength, and fatigue ${ }^{1}$. Healthcare professionals, especially those that are daily caring for patients, are among the professions with the highest WRMD rates ${ }^{2}$, which impairs the performance of work activities, going from the limitation of movements to temporary disability ${ }^{3}$. A study showed that in physiotherapists, the prevalence of WRMD throughout the life was $91 \%$ and that one in every six physiotherapists changed the working area or left the profession due to some WRMD 4 .

The constant transfer of patients, the maintenance of inadequate body posture and the performance of manual activities, routinely executed by physiotherapists ${ }^{5}$ that work in the hospital wards can be highlighted as one of the main biomechanical risk factors for the development of WRMD.

On the other hand, the intensive care unit (ICU) is seen as the most stressing, traumatizing and aggressive hospital environment, due to its intense work routine and the diverse stressing situations such as the frequent patients' crises, the intermittent noises from monitors, aspiration pumps, respirators, as well as moans, cries of pain and wheeping ${ }^{6}$.

However, although several factors have been observed, both biomechanical and emotional, that can contribute to the onset of WRMD in physiotherapists, we still do not know whether those professionals working in a university hospital will present a working sector-related musculoskeletal symptom (ICU and ward) and if, after 12 months working in that university hospital, the prevalence of these symptoms will be the same as that of the time of admission in that hospital service.

Based on the above, the objectives of this study were: (i) to compare the self-reported pain and musculoskeletal discomfort among physiotherapists of the ICU and wards of a university hospital and (ii) to retrospectively evaluate, after 12 months of work, the self-reported pain and musculoskeletal discomfort of physiotherapists who work in the ICU and wards of this hospital.

The assumption was that it would have an association between the self-reported pain and musculoskeletal discomfort and: (i) the working sector of these physiotherapists in this university hospital, (ii) the working time of these professionals, both in the ICU and wards of this hospital.

\section{METHODS}

This is a retrospective cohort study. The University Hospital (UH) database of the Federal University of Vale de São Francisco (UNIVASF) / Brazilian Company of Hospital Services (EBSERH) was accessed to evaluate the data of self-reported pain and musculoskeletal discomfort of each of the 18 active physiotherapists of the UH-UNIVASF/EBSERH/. The data acquired between February and August 2015 (T1) was retrospectively compared with the existing data in the database at the admission of the UH employees (T0). These data were evaluated using the adapted version translated to Portuguese of the Nordic Musculoskeletal Questionnaire (NMQ), encompassing all the anatomical areas of the body. So, the entire population of physiotherapists of the UH-UNIVASF $(n=18)$ was presently evaluated (T1) and then compared with the retrospective data acquired one year before (T0), at the admission moment of these professionals. It is worth mentioning that both evaluations, at admission (T0) and the present ones (T1) were performed by the same researcher. In these evaluations it was considered: (i) the symptoms in last the 12 months, (ii) if there was any impairment to carry out the normal activities because of this problem in last the 12 months; (iii) if a healthcare professional has been consulted because of this condition in last 12 months e (iv) the symptoms in last the 7 days. The data collection, both at T0 and T1, was performed in individual sessions, in these professionals' work environment. Initially, a questionnaire to evaluate the demographic, anthropometric and occupational data of the physiotherapists was applied, as well as the existence of a second work shift and International Physical Activity Questionnaire $(\mathrm{IPAQ})^{7}$ to evaluate the level of physical activity.

\section{Statistical analysis}

The Statistical Package for Social Sciences (SPSS) software, version 22.0 was used. First, the normality was tested (Shapiro-Wilk test) and the homoscedasticity (Levene test) of the following variables: age (years), mass $(\mathrm{kg})$, height $(\mathrm{m})$, body mass index $\left(\mathrm{kg} / \mathrm{m}^{2}\right)$. The data referring to the presence or absence (dichotomic) of musculoskeletal symptoms were presented using descriptive statistics in absolute and percentage numbers for each of the groups. McNemar test was also used to check the associations, (self-reported pain and musculoskeletal discomfort and the work sector; and also, the selfreported pain and musculoskeletal discomfort and a second work shift and the level of physical activity) in the studied groups.

The level of significance of 0.05 was adopted for significant differences.

\section{RESULTS}

Of the total of 18 physiotherapists $(n=18)$ of this $\mathrm{UH}, 15$ $(83 \%)$ were female. Of these 18 physiotherapists, 11 (61\%) worked in the ICU and had the following anthropometric characteristics: $30 \pm 5$ years; $63.42 \pm 8.06 \mathrm{~kg} ; 1.66 \pm 0.06 \mathrm{~m}$; $23.09 \pm 2.56 \mathrm{~kg} / \mathrm{m}^{2}$ and seven $(39 \%)$ in the wards, whose anthropometric characteristics were: $31 \pm 5$ years; $64.54 \pm 10.34 \mathrm{~kg}$; $1.72 \pm 0.10 \mathrm{~m} ; 21.93 \pm 3.03 \mathrm{~kg} / \mathrm{m}^{2}$, thus forming the two studied groups (ICU and ward).

In the ICU, 10 (91\%) of the physiotherapists were female with age of $30 \pm 5$ years, having the following anthropometric data: $63.96 \pm 8.29 \mathrm{~kg} ; 1.65 \pm 0.06 \mathrm{~m} ; 23.39 \pm 2.48 \mathrm{~kg} / \mathrm{m}^{2}$. The only male physiotherapist (9\%) was 29 years old; $58 \mathrm{~kg} ; 1.70 \mathrm{~m}$; $20.07 \mathrm{~kg} / \mathrm{m}^{2}$. In the ward sector, there were five female physiotherapists $(71 \%)$, with age of $31 \pm 6$ years, with the following anthropometric characteristics: $59.96 \pm 6.63 \mathrm{~kg} ; 1.69 \pm 0.11 \mathrm{~m}$, 
$20.95 \pm 1.99 \mathrm{~kg} / \mathrm{m}^{2}$ and two $(29 \%)$ male physiotherapists with age of $30 \pm 1$ years with the following anthropometric characteristics: $76 \pm 9.90 \mathrm{~kg} ; 1.77 \pm 0.06 \mathrm{~m} ; 24.40 \pm 4.72 \mathrm{~kg} / \mathrm{m}^{2}$.

The ICU and ward groups were homogeneous regarding age, mass, height and body mass index.

Regarding the level of physical activity, evaluated by the IPAQ Brazilian version ${ }^{7}$ and classified as low, moderate and high, it was observed that in the ICU physiotherapists group, (40\%; $\mathrm{n}=4)$ had a low level, $(50 \% ; \mathrm{n}=5)$ moderate and $(10 \% ; \mathrm{n}=1)$ high. In the ward group, $(14 \% ; n=1)$ had low level, $(57 \%$; $\mathrm{n}=4)$ moderate and $(29 \% ; \mathrm{n}=2)$ high. When characterizing the physiotherapists' population of this university hospital $(n=18)$ in regarding the level of physical activity, there was no association between the work sector and the level physical activity low $(\mathrm{p}=0.338)$, moderate $(\mathrm{p}=1)$ and high $(\mathrm{p}=0.536)$.

Of the 11 physiotherapists of the ICU, at T0, six (55\%) have reported some type of musculoskeletal symptom in last the 12 months, and the higher prevalence was in the neck region $(27 \% ; n=3)$ and lower back $(18 \% ; n=2)$. Three $(27 \%)$ physiotherapists of this sector reported the need to see a healthcare professional because of the pain and the discomfort in the region of the shoulder $(9 \% ; n=1)$, lower back $(9 \% ; n=1)$ and hip and thighs $(9 \% ; n=1)$. One $(9 \%)$ of the interviewed participant of this group reported pain and musculoskeletal discomfort in at least one of the body regions in last seven days. The physiotherapists of this sector did not report the need for a leave of absence due to the symptoms, as shown in tables 1 and 3 .

Of the seven physiotherapists of the ward, also at the T0 period, only one (14\%) reported some type of musculoskeletal symptom in last the 12 months, referring to the neck region. None of the participants of this group reported pain and musculoskeletal discomfort in the last seven days, nor the need for a leave of absence due to the symptoms or need to seek a healthcare professional because of the pain and discomfort, as shown in tables 1 and 3 .

After 12 months of work (T1), of the 11 ICU physiotherapists, nine $(82 \%)$ reported some type of musculoskeletal symptom in the last 12 months, and the prevalences were the region of neck $(55 \% ; n=6)$, upper back $(27 \% ; n=3)$, lower back $(27 \% ; n=3)$ and hip and thighs $(27 \% ; n=3)$. Two physiotherapists of this sector (18\%) reported the need to see a healthcare professional because of the pain and the discomfort in the lower back $(9 \% ; n=1)$, and hip and thighs $(9 \%$; $\mathrm{n}=1)$. Four respondents in this group $(36 \%)$ reported musculoskeletal symptoms in at least one of the body regions in the last seven days, and the prevalences were the neck region $(18 \% ; n=2)$, upper back $(18 \% ; n=2)$ and lower back $(18 \%$; $\mathrm{n}=2$ ). The physiotherapists of this sector did not report the need for a leave of absence due to the symptoms, as shown in tables 2 and 3 .

After 12 months of work (T1) in this university hospital, all the ward physiotherapists reported some type of musculoskeletal symptom in the last 12 months, and the prevalences were in the upper back $(71 \% ; n=5)$, shoulders $4(57 \%)$ and lower back 3 (43\%). Two physiotherapists of this sector $(29 \%)$ reported the need to see a healthcare professional because of the pain and the discomfort in the lower back $(14 \% ; n=1)$, and hip and thighs $(14 \% ; n=1)$. Five respondents in this group (71\%) reported musculoskeletal symptoms in at least one of the body regions in the last seven days, and the prevalences were the lower back ( $43 \% ; n=3)$, and upper back $(29 \% ; n=2)$. One physiotherapist (14\%) reported the need for a leave of absence due to the symptoms, as shown in tables 2 and 3.

Table 1. Association between self-reported pain and musculoskeletal discomfort in the two groups (T0)

\begin{tabular}{|c|c|c|c|c|c|c|c|c|c|c|c|c|}
\hline \multirow[t]{4}{*}{$\begin{array}{l}\text { Anatomical } \\
\text { regions }\end{array}$} & \multicolumn{2}{|c|}{$\begin{array}{l}\text { Symptoms in last } \\
\text { the } 12 \text { months }\end{array}$} & \multicolumn{4}{|c|}{$\begin{array}{l}\text { Impairment to } \\
\text { perform normal } \\
\text { activities because } \\
\text { of this problem in } \\
\text { the last } 12 \text { months }\end{array}$} & \multicolumn{2}{|c|}{$\begin{array}{l}\text { Consultation with } \\
\text { a healthcare pro- } \\
\text { fessional because } \\
\text { of this condition in } \\
\text { the last } 12 \text { months }\end{array}$} & \multicolumn{4}{|c|}{$\begin{array}{l}\text { Symptoms in the } \\
\text { last } 7 \text { days }\end{array}$} \\
\hline & \multicolumn{2}{|c|}{$\mathrm{n}=6(33 \%)$} & \multicolumn{4}{|c|}{$\mathrm{n}=0(0 \%)$} & \multicolumn{2}{|c|}{$\mathrm{n}=3(17 \%)$} & \multicolumn{4}{|c|}{$\mathrm{n}=2(11 \%)$} \\
\hline & \multicolumn{2}{|c|}{ T0 } & \multicolumn{4}{|c|}{ TO } & \multicolumn{2}{|c|}{ TO } & \multicolumn{4}{|c|}{ T0 } \\
\hline & ICU & Ward & $\begin{array}{c}\mathrm{p} \\
\text { value }\end{array}$ & ICU & Ward & $\begin{array}{c}\mathrm{p} \\
\text { value }\end{array}$ & $\mathrm{ICU}$ & Ward & $\begin{array}{c}\mathrm{p} \\
\text { value }\end{array}$ & $\mathrm{ICU}$ & Ward & $\begin{array}{c}p \\
\text { value }\end{array}$ \\
\hline Neck & $3(27 \%)$ & $1(14 \%)$ & 0.505 & $0(0 \%)$ & $0(0 \%)$ & $\S$ & $0(0 \%)$ & $0(0 \%)$ & $\S$ & $0(0 \%)$ & $0(0 \%)$ & $\S$ \\
\hline Shoulder & $1(9 \%)$ & $0(0 \%)$ & 1 & $0(0 \%)$ & $0(0 \%)$ & $\S$ & $1(9 \%)$ & $0(0 \%)$ & 1 & $0(0 \%)$ & $0(0 \%)$ & $\S$ \\
\hline $\begin{array}{l}\text { Upper } \\
\text { back }\end{array}$ & $1(3 \%)$ & $0(0 \%)$ & 1 & $0(0 \%)$ & $0(0 \%)$ & $\S$ & $0(0 \%)$ & $0(0 \%)$ & $\S$ & $0(0 \%)$ & $0(0 \%)$ & $\S$ \\
\hline Elbow & $0(0 \%)$ & $0(0 \%)$ & $\S$ & $0(0 \%)$ & $0(0 \%)$ & $\S$ & $0(0 \%)$ & $0(0 \%)$ & $\S$ & $0(0 \%)$ & $0(0 \%)$ & $\S$ \\
\hline Wrist/hands & $0(0 \%)$ & $0(0 \%)$ & $\S$ & $0(0 \%)$ & $0(0 \%)$ & $\S$ & $0(0 \%)$ & $0(0 \%)$ & $\S$ & $0(0 \%)$ & $0(0 \%)$ & $\S$ \\
\hline $\begin{array}{l}\text { Lower } \\
\text { back }\end{array}$ & $2(18 \%)$ & $0(0 \%)$ & 0.496 & $0(0 \%)$ & $0(0 \%)$ & $\S$ & $1(9 \%)$ & $0(0 \%)$ & 1 & $0(0 \%)$ & $0(0 \%)$ & $\S$ \\
\hline Hip/thighs & $1(9 \%)$ & $0(0 \%)$ & 1 & $0(0 \%)$ & $0(0 \%)$ & $\S$ & $1(9 \%)$ & $0(0 \%)$ & 1 & $1(9 \%)$ & $0(0 \%)$ & 1 \\
\hline Knees & $0(0 \%)$ & $0(0 \%)$ & $\S$ & $0(0 \%)$ & $0(0 \%)$ & $\S$ & $0(0 \%)$ & $0(0 \%)$ & $\S$ & $0(0 \%)$ & $0(0 \%)$ & $\S$ \\
\hline Ankle/foot & $0(0 \%)$ & $0(0 \%)$ & $\S$ & $0(0 \%)$ & $0(0 \%)$ & $\S$ & $0(0 \%)$ & $0(0 \%)$ & $\S$ & $0(0 \%)$ & $0(0 \%)$ & $\S$ \\
\hline
\end{tabular}

$\mathrm{ICU}=$ intensive care unit; Ward $=$ wards; $\S=$ absence of value to perform Fisher's Exact test. 
In the present study, there was no association between the selfreported pain and musculoskeletal discomfort and the work sectors of these professionals (Tables 1 and 2). However, it was observed a temporal association between the reporting of the symptoms in last the 12 months in the ICU sector in the regions of the shoulder $(p=0.027)$, wrist/hand $(p=0.008)$ and knees $(\mathrm{p}=0.013)$ and a temporal association between the reporting of the symptoms in last the 12 months in the ward sector in the wrist/hand $(p=0,041)$, hip/thighs $(p=0.041)$ and knees $(p=0.041)$. A temporal association was also observed between the self-reported pain and discomfort only in the ICU sector in the regions of the neck $(p=0.043)$, shoulder $(p=0.009)$, upper back $(\mathrm{p}=0.043)$, lower back $(\mathrm{p}=0.043)$ and hip and thighs $(\mathrm{p}=0.027)$ in last the 7 days, as shown in table 3 .

The second working shift of these physiotherapists did not seem to be associated with the reported pain and musculoskeletal discomfort in the last 12 months (T1) in the physiotherapists of these sectors (Table 4).

Table 2. Association between self-reported pain and musculoskeletal discomfort in the two groups after 12 months (T1)

\begin{tabular}{|c|c|c|c|c|c|c|c|c|c|c|c|c|}
\hline \multirow[t]{4}{*}{$\begin{array}{l}\text { Anatomical } \\
\text { regions }\end{array}$} & \multicolumn{2}{|c|}{$\begin{array}{l}\text { Symptoms in last } \\
\text { the } 12 \text { months }\end{array}$} & \multicolumn{4}{|c|}{$\begin{array}{l}\text { Impairment to } \\
\text { perform normal } \\
\text { activities because } \\
\text { of this problem in } \\
\text { the last } 12 \text { months }\end{array}$} & \multicolumn{2}{|c|}{$\begin{array}{l}\text { Consultation with } \\
\text { a healthcare pro- } \\
\text { fessional because } \\
\text { of this condition in } \\
\text { the last } 12 \text { months }\end{array}$} & \multicolumn{4}{|c|}{$\begin{array}{l}\text { Symptoms in the } \\
\text { last } 7 \text { days }\end{array}$} \\
\hline & \multicolumn{2}{|c|}{$n=16(89 \%)$} & \multicolumn{4}{|c|}{$\mathrm{n}=1(6 \%)$} & \multicolumn{2}{|c|}{$\mathrm{n}=4(22 \%)$} & \multicolumn{4}{|c|}{$\mathrm{n}=9$ (50\%) } \\
\hline & \multicolumn{2}{|c|}{$\mathrm{T} 1$} & \multicolumn{4}{|c|}{ T1 } & \multicolumn{2}{|c|}{$\mathrm{T} 1$} & \multicolumn{4}{|c|}{$\mathrm{T} 1$} \\
\hline & ICU & Ward & $\begin{array}{c}\mathrm{p} \\
\text { value }\end{array}$ & ICU & Ward & $\begin{array}{c}\mathrm{p} \\
\text { value }\end{array}$ & ICU & Ward & $\begin{array}{c}\mathrm{p} \\
\text { value }\end{array}$ & ICU & Ward & $\begin{array}{c}\mathrm{p} \\
\text { value }\end{array}$ \\
\hline Neck & $6(55 \%)$ & 2 (29\%) & 0.334 & $0(0 \%)$ & $0(0 \%)$ & $\S$ & $0(0 \%)$ & $0(0 \%)$ & $\S$ & $2(18 \%)$ & $1(14 \%)$ & 1 \\
\hline Shoulder & $1(9 \%)$ & $4(57 \%)$ & 0.100 & $0(0 \%)$ & $0(0 \%)$ & $\S$ & $0(0 \%)$ & $0(0 \%)$ & $\S$ & $1(9 \%)$ & $1(14 \%)$ & 1 \\
\hline $\begin{array}{l}\text { Upper } \\
\text { back }\end{array}$ & $3(27 \%)$ & $5(71 \%)$ & 0.153 & $0(0 \%)$ & $0(0 \%)$ & $\S$ & $0(0 \%)$ & $0(0 \%)$ & $\S$ & 2 (18\%) & 2 (29\%) & 1 \\
\hline Elbow & $0(0 \%)$ & $0(0 \%)$ & $\S$ & $0(0 \%)$ & $0(0 \%)$ & $\S$ & $0(0 \%)$ & $0(0 \%)$ & $\S$ & $0(0 \%)$ & $0(0 \%)$ & $\S$ \\
\hline Wrist/hands & $1(9 \%)$ & $1(14 \%)$ & 1 & $0(0 \%)$ & $0(0 \%)$ & $\S$ & $0(0 \%)$ & $0(0 \%)$ & $\S$ & $0(0 \%)$ & $1(14 \%)$ & 0.411 \\
\hline $\begin{array}{l}\text { Lower } \\
\text { back }\end{array}$ & $3(27 \%)$ & $3(43 \%)$ & 0.643 & $0(0 \%)$ & $1(14 \%)$ & 0,411 & $1(9 \%)$ & $1(14 \%)$ & 1 & $2(18 \%)$ & $3(43 \%)$ & 0.592 \\
\hline Hip/thighs & $3(27 \%)$ & 1 (14\%) & 0.602 & $0(0 \%)$ & $0(0 \%)$ & $\S$ & $1(9 \%)$ & $1(14 \%)$ & 1 & $1(9 \%)$ & $1(14 \%)$ & 1 \\
\hline Knees & $2(18 \%)$ & $1(14 \%)$ & 1 & $0(0 \%)$ & $0(0 \%)$ & $\S$ & $0(0 \%)$ & $0(0 \%)$ & $\S$ & $0(0 \%)$ & $0(0 \%)$ & $\S$ \\
\hline Ankle/foot & $1(9 \%)$ & 2 (29\%) & 0.536 & $0(0 \%)$ & $0(0 \%)$ & $\S$ & $0(0 \%)$ & $0(0 \%)$ & $\S$ & $0(0 \%)$ & $1(14 \%)$ & 0,411 \\
\hline
\end{tabular}

ICU = intensive care unit; Ward = wards; $\S=$ absence of value to perform Fisher's Exact test.

Table 3. Association between self-reported pain and musculoskeletal discomfort by the physiotherapists and the work time of the physiotherapists in both groups

\begin{tabular}{|c|c|c|c|c|c|c|c|c|c|c|c|c|c|}
\hline \multirow[t]{2}{*}{ Sector } & \multirow[b]{2}{*}{$\begin{array}{l}\text { Region } \\
\text { body }\end{array}$} & \multicolumn{3}{|c|}{$\begin{array}{l}\text { Symptoms in the last } \\
12 \text { months }\end{array}$} & \multicolumn{3}{|c|}{$\begin{array}{l}\text { Impairment to perform } \\
\text { normal activities because } \\
\text { of this problem in the last } \\
12 \text { months }\end{array}$} & \multicolumn{3}{|c|}{$\begin{array}{l}\text { Consultation with a } \\
\text { healthcare professional } \\
\text { because of this condition } \\
\text { in the last } 12 \text { months }\end{array}$} & \multicolumn{3}{|c|}{$\begin{array}{c}\text { Symptoms in the last } \\
7 \text { days }\end{array}$} \\
\hline & & T0 & $\mathrm{T} 1$ & $\begin{array}{c}\mathrm{p} \\
\text { value }\end{array}$ & T0 & T1 & $\begin{array}{c}p \\
\text { value }\end{array}$ & T0 & $\mathrm{T} 1$ & $\begin{array}{c}\mathrm{p} \\
\text { value }\end{array}$ & TO & $\mathrm{T} 1$ & $p$ value \\
\hline \multirow[t]{9}{*}{ ICU } & Neck & $3(27 \%)$ & $6(55 \%)$ & 1,000 & $0(0 \%)$ & $0(0 \%)$ & $\S$ & $0(0 \%)$ & $0(0 \%)$ & $\S$ & $0(0 \%)$ & $2(18 \%)$ & 0.043 \\
\hline & Shoulder & 1 (9\%) & 1 (9\%) & 0,027 & $0(0 \%)$ & $0(0 \%)$ & $\S$ & 1 (9\%) & $0(0 \%)$ & 0,016 & $0(0 \%)$ & 1 (9\%) & 0.009 \\
\hline & $\begin{array}{l}\text { Upper } \\
\text { back }\end{array}$ & $1(3 \%)$ & 3 (27\%) & 0,078 & $0(0 \%)$ & $0(0 \%)$ & $\S$ & $0(0 \%)$ & $0(0 \%)$ & $\S$ & $0(0 \%)$ & $2(18 \%)$ & 0.043 \\
\hline & Elbow & $0(0 \%)$ & $0(0 \%)$ & $\S$ & $0(0 \%)$ & $0(0 \%)$ & $\S$ & $0(0 \%)$ & $0(0 \%)$ & $\S$ & $0(0 \%)$ & $0(0 \%)$ & $\S$ \\
\hline & Wrist & $0(0 \%)$ & 1 (9\%) & 0,008 & $0(0 \%)$ & $0(0 \%)$ & $\S$ & $0(0 \%)$ & $0(0 \%)$ & $\S$ & $0(0 \%)$ & $0(0 \%)$ & $\S$ \\
\hline & $\begin{array}{l}\text { Lower } \\
\text { back }\end{array}$ & 2 (18\%) & $3(27 \%)$ & 0,182 & $0(0 \%)$ & $0(0 \%)$ & $\S$ & $1(9 \%)$ & 1 (9\%) & 0,027 & $0(0 \%)$ & $2(18 \%)$ & 0.043 \\
\hline & Hip/thighs & $1(9 \%)$ & $3(27 \%)$ & 0,077 & $0(0 \%)$ & $0(0 \%)$ & $\S$ & $1(9 \%)$ & 1 (9\%) & 0,027 & $1(9 \%)$ & $1(9 \%)$ & 0.027 \\
\hline & Knee & $0(0 \%)$ & 2 (18\%) & 0,013 & $0(0 \%)$ & $0(0 \%)$ & $\S$ & $0(0 \%)$ & $0(0 \%)$ & $\S$ & $0(0 \%)$ & $0(0 \%)$ & $\S$ \\
\hline & Ankle/foot & $0(0 \%)$ & $1(9 \%)$ & 0,078 & $0(0 \%)$ & $0(0 \%)$ & $\S$ & $0(0 \%)$ & $0(0 \%)$ & $\S$ & $0(0 \%)$ & $0(0 \%)$ & $\S$ \\
\hline
\end{tabular}


Table 3. Association between self-reported pain and musculoskeletal discomfort by the physiotherapists and the work time of the physiotherapists in both groups - continuation

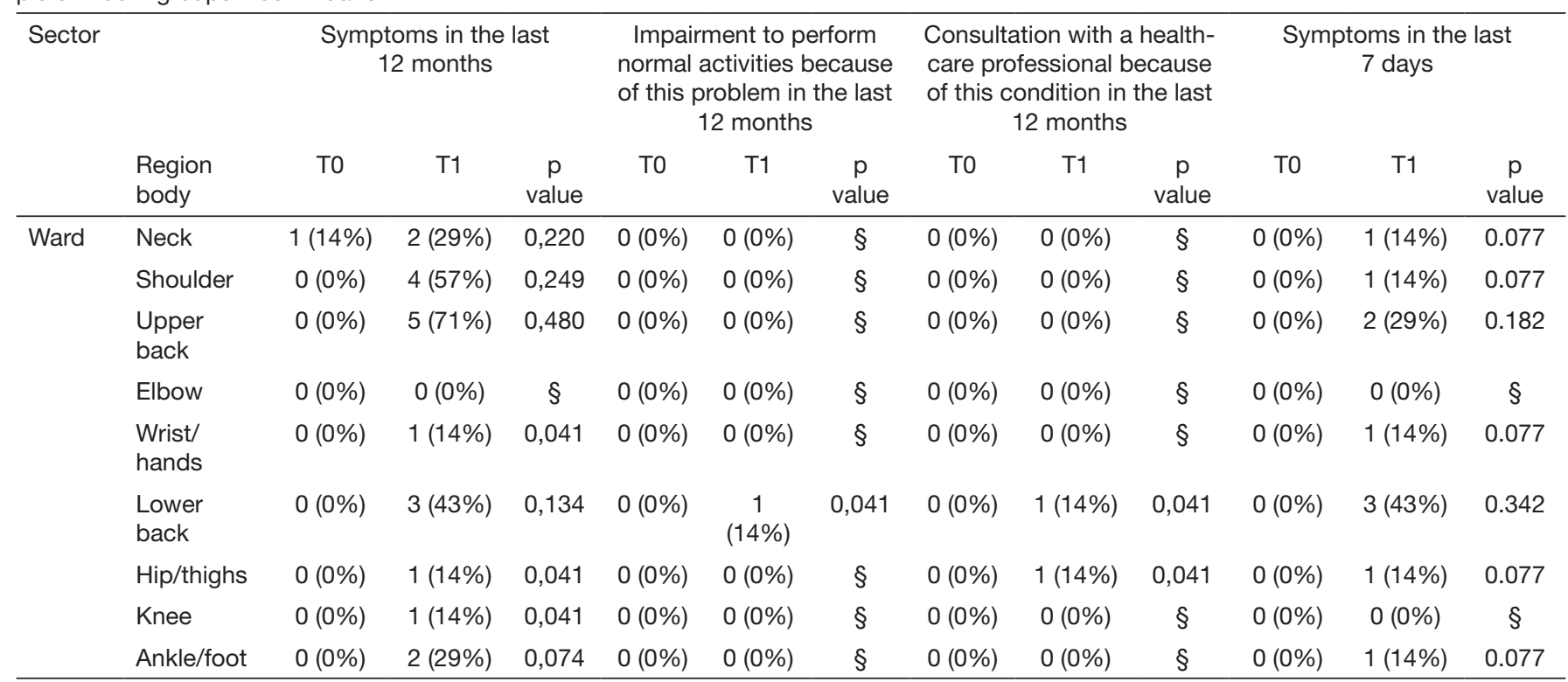

$\mathrm{ICU}=$ intensive care unit; Ward = wards; $\mathrm{T} 1$ = after 12 months; $\mathrm{T} 0$ = at admission; $\S$ Absence of value to perform McNemar test.

Table 4. Association between self-reported pain and musculoskeletal discomfort by the physiotherapists in the last 12 months (T1) and the second work shift in both groups

\begin{tabular}{|c|c|c|c|c|}
\hline \multirow[t]{2}{*}{ Sector } & \multirow{2}{*}{$\begin{array}{l}\text { Pain and } \\
\text { discomfort } \\
\text { Body } \\
\text { region }\end{array}$} & \multicolumn{3}{|c|}{ Symptoms in last the 12 months (T1) } \\
\hline & & $\begin{array}{c}\text { Without 2nd } \\
\text { shift } \\
n=12(67 \%)\end{array}$ & $\begin{array}{c}\text { With } 2 \text { nd } \\
\text { shift } \\
n=6(33 \%)\end{array}$ & $p$ value \\
\hline \multirow[t]{9}{*}{ ICU } & Neck & 5 & 1 & 1 \\
\hline & Shoulder & 1 & 0 & 1 \\
\hline & $\begin{array}{l}\text { Upper } \\
\text { back }\end{array}$ & 2 & 1 & 1 \\
\hline & Elbow & 0 & 0 & $\S$ \\
\hline & Wrist & 0 & 1 & 0.300 \\
\hline & $\begin{array}{l}\text { Lower } \\
\text { back }\end{array}$ & 2 & 1 & 1 \\
\hline & Hip/thighs & 3 & 0 & 0.475 \\
\hline & Knee & 2 & 0 & 1 \\
\hline & Ankle & 0 & 1 & 0.300 \\
\hline \multirow[t]{9}{*}{ Ward } & Neck & 2 & 0 & 0.428 \\
\hline & Shoulder & 3 & 1 & 0.485 \\
\hline & $\begin{array}{l}\text { Upper } \\
\text { back }\end{array}$ & 3 & 2 & 1 \\
\hline & Elbow & 0 & 0 & $\S$ \\
\hline & Wrist & 1 & 0 & 1 \\
\hline & $\begin{array}{l}\text { Lower } \\
\text { back }\end{array}$ & 1 & 2 & 1 \\
\hline & Hip/thighs & 1 & 0 & 1 \\
\hline & Knee & 1 & 0 & 1 \\
\hline & Ankle/foot & 2 & 0 & 0.428 \\
\hline
\end{tabular}

\section{DISCUSSION}

The first assumption that it would have an association between the self-report of these symptoms and the work sector of the physiotherapists in this hospital was rejected since the current results show no association regarding the selfreported pain and musculoskeletal discomfort in the T0-T1 period and the sector for most of the body segments in both groups.

We start this discussion keeping in mind that among the several attributions of the physiotherapists we can highlight the activities going from the assessment of the vital signs and monitoring of the patient to aspiration procedures, changes in the patient's position and passive exercises that require physical strength and standing for long periods ${ }^{9}$. Moreover, patients' instability during treatment, especially during unexpected movement and the possibility of falling may require immediate and abrupt motor responses from the physiotherapists, generating musculoskeletal overload, especially on the spine. ${ }^{10}$. However, despite some biomechanical differences to perform the work attributions of the physiotherapists in the ICU and ward, they did not contribute to an association between pain complaints and the work sector of the physiotherapists in both moments of assessment.

Olkowski and Stolf $\mathrm{i}^{11}$ state that female physiotherapists are more prone to develop pain and musculoskeletal discomfort than male. This can be explained by the fact that women are generally shorter with lower body mass than men, which generates physical disadvantages when performing their activities $^{12,13}$. However, possibly because the majority of the sample be of female, no association was observed regarding the work sector (ICU and ward) and self-reported pain and musculoskeletal discomfort by these physiotherapists. 
Another aspect observed was that only a small number of physiotherapists $(n=4)$ sought a healthcare professional help because of the reported musculoskeletal symptoms. The cultural factor may partly account for this behavior. According to Campo et al. ${ }^{14}$, one of the main beliefs inherent to the physiotherapy culture, regardless the working sector, is that physiotherapists are knowledgeable and capable of treating themselves. Thus, this belief, according to this study, was expressed as an expectation that the participants would not have any work-related musculoskeletal disorder because they knew the "right" way to perform their tasks.

The second assumption that it would have an association between the self-reported pain and musculoskeletal discomfort and the time of work of these physiotherapists, both in the ICU and ward of this hospital, was partially confirmed since only the physiotherapists working in the ICU had self-reported musculoskeletal symptoms in the last 7 days, in the shoulders, spine, hip, and thighs. Despite the size and the resistive force of the spine vertebrae, as well as the muscles and ligaments grouping, this region is subjected to constant overload since the weight of all the upper segment of the trunk, head, and upper limbs is transmitted for this body segment ${ }^{10}$ and the incidence of lumbar pain is associated with the isometric and isokinetic weakness of the torso extensor, while its gravity is associated with the weakness of the torso flexors ${ }^{15}$. The fact that the physiotherapists of this sector need to perform routinely, standing, activities of passive mobilization of patients' lower and upper limbs, as well as lung drainage and respiratory maneuvers, can justify the increase of self-reported musculoskeletal symptoms in the regions of the spine, hip and thighs. Moreover, the inclination of the torso during the performance of these activities, and the repetition of movement patterns in non-ergonomic positions are the main postures that lead to musculoskeletal complaints ${ }^{16,17}$. Thus, it can be noted that the musculoskeletal complaints can be directly related to the body postures adopted during the performance of the different motor skills, and that prevention measures must be planned according to the analysis of the body movement and posture ${ }^{18,19}$.

According to Campos et al. ${ }^{14}$, physiotherapists who transfer patients from six to 10 times per day had 2.4 more chances to develop WRMD than those who did not perform this type of activity. It is known that in the wards, the physiotherapists end up performing this procedure more frequently. However, no association was observed between the work sector and the selfreported pain and musculoskeletal discomfort.

It is also reasonable to think that many physiotherapists, regardless the sector (ICU or ward), end up experiencing similar work conditions in the biomechanics point of view, what could equally expose these professionals to WRMD and, consequently to musculoskeletal symptoms. Nonetheless, the results of the present study shown a temporal association (admission $\mathrm{x}$ current time) only in the ICU group of physiotherapists. This can be explained by the fact that the stressing, traumatizing and aggressive environment inherent to the $\mathrm{ICU}^{6} \mathrm{can}$, over time, increase the perception of the self-reported pain and musculoskeletal discomfort by ICU physiotherapists and not the physiotherapists working in the ward. In this sector, the pain perception can be even bigger since according to Hudak and Gallo ${ }^{6}$, this is a highly stressing environment due to the intense work routine, the constant contagion risks, the possible needlestick accidents, the frequent crises situations, the intermittent noises of monitors, aspiration pumps, respirators, as well as moans, cries of pain and weeping.

There was a temporal association between the self-reported pain and musculoskeletal discomfort in the shoulder, wrist/hands and knees in the ICU in the last 12 months, which shows that the physiotherapists of this sector had already reported musculoskeletal symptoms. Although in the ward sector there has been a temporal association with the self-reported pain and musculoskeletal discomfort in the wrist/hand, hip/thighs and knee, these symptoms did not perpetuate, which can be explained by the exposure to the risk factors in the previous workstation.

Another aspect that is worth mentioning is the age of the physiotherapists in this study. Cromie, Robertson and Best ${ }^{4}$ showed the big prevalence of pain and musculoskeletal discomfort complaints in young physiotherapists in the first years of work. According to the authors, this can be explained by the apparent lack of experience and training of these physiotherapists when using specific treatment techniques that can lead to unfavorable ergonomic situations that aggravate or cause the musculoskeletal discomfort in these professionals. According to Cromie, Robertson and Best ${ }^{4}$, as time goes by and the professional gains experience, a reduction in the incidence of these musculoskeletal disorders in physiotherapists will be observed. Regarding experience and training, we can also include the capacity to deal with this stressing environment that, somehow can explain the fact of finding a temporal association only in the ICU environment and not in the ward.

In addition to the mental stress, other risk factors as short stature, improper nutrition, lifestyle and psychosocial factors seem to be related to the onset of musculoskeletal complaints in physiotherapists ${ }^{10}$. No association was observed between the musculoskeletal symptoms and the level of physical activity in both groups. On the other hand, since it was not the objective of the present study, we did not assess the nutritional aspect and the psychosocial factors of these physiotherapists, which limits our discussion on these aspects.

Even though it was observed in the literature a higher prevalence of musculoskeletal complaints in overweight physiotherapists ${ }^{20}$, the studied groups did not present significant difference, neither throughout time, for this anthropometric variable.

Another point raised in the literature is the working hours, which has been associated with the prevalence of WRMD ${ }^{21}$. However, the second working shift of these physiotherapists did not seem to be associated with the pain and musculoskeletal discomfort reported by the physiotherapists of these sectors. Thus, for this University hospital, we cannot say the workload is a predictor of the onset of musculoskeletal pain and discomfort.

Factors related to the work environment, as the lack of equipment or non-ergonomic work equipment, make difficult the labor activities of the professionals and become a potential hazard 
for the development of WRMD ${ }^{10,22}$. However, these ergonomic aspects were not evaluated since they were not the specific objectives of this study and they should be considered here as a suggestion for future studies.

Although all the physiotherapists of this public university hospital have been assessed $(n=18)$, thus working with a population and not with a sample, we suggest further studies that evaluate, prospectively or retrospectively, the physiotherapists of other Brazilian university hospitals to better support future multi-professional interventions directed to these healthcare professionals who much contribute to the recovery process of hospitalized patients.

\section{CONCLUSION}

The self-reported pain and musculoskeletal discomfort of physiotherapists of a university hospital, both at admission (T0) and after 12 months of work (T1) do not seem to be associated with the working sector of these professionals. However, after 12 months, the physiotherapists who work in the ICU showed an increase in the number of self-reported pain and musculoskeletal discomfort.

\section{REFERENCES}

1. Baptista PC, Merighi MA, Silva A. Angústia de mulheres trabalhadoras de enfermagem que adoecem por distúrbios osteomusculares relacionados ao trabalho. Rev Bras Enferm. 2011;64(3):438-44

2. Alexopoulos EC, Tanagra D, Detorakis I, Gatsi P, Goroyia A, Michalopoulou M, et al. Knee and low back complaints in professional hospital nurses: occurrence, chronicity, care seeking and absenteeism. Work. 2011;38(4):329-35.

3. Lima JP, Sousa AP, Santos EV, Bezerra AL, Sousa MN. Prevalência de distúrbios osteomioarticulares e algias em fisioterapeutas. Rev Saúde Públ Santa Cat. 2015;8(3):98-108.

4. Cromie JE, Robertson VJ, Best MO. Work-related musculoskeletal disorders in physical therapists: prevalence, severity, risks, and responses. Phys Ther. 2000;80(4):336-51.
5. Rodrigues AR, Pedro R. Prevalência de lesôes músculo-esqueléticas relacionadas com o trabalho em fisioterapeutas portugueses e fatores de risco associados. Rev Ciênc Saúde ESSCVP. 2013;5(1):9-23.

6. Hudak C, Gallo B. Cuidados intensivos de enfermagem - uma abordagem holística. $6^{\mathrm{a}}$ ed. Rio de Janeiro: 1997.

7. IPAQ G. (IPAQ G. Guidelines for Data Processing and Analysis of the International Physical Activity Questionnaire (IPAQ) 2005 [07/02/2016]. Available from: http:// www.ipaq.ki.se.

8. De Barros E, Alexandre NM. Cross-cultural adaptation of the Nordic musculoskeletal questionnaire. Int Nurs Rev. 2003;50(2):101-8.

9. Pour HA, Ozvurmaz S, Tipirdamaz B, Gundogmus EE. The prevalence, severity and occupational risk factors of low back pain among ICU nurses. Ulutas Med J. 2016;2(3):138-47.

10. Anyfantis I, Biska A. Musculoskeletal disorders among Greek physiotherapists. Traditional and emerging risk factors. Saf Health Work. 2017:1-5.

11. Olkowski BF, Stolfi AM. Safe patient handling perceptions and practices: a survey of acute care physical therapists. Phys Ther. 2014;94(5):682-95.

12. Magnago TS, Lisboa MTL, Griep R, Kirchhof AL, Camponogara S, Nonnenmacher CQ, et al. Condiçóes de trabalho, características sociodemográficas e distúrbios musculoesqueléticos em trabalhadores de enfermagem. Acta Paul Enferm. 2010;23(2):187-93.

13. Iqbal Z, Alghadir A. Prevalence of work-related musculoskeletal disorders among physical therapists. Med Pr. 2015;66(4):459-69.

14. Campo M, Weiser S, Koenig KL, Nordin M. Work-related musculoskeletal disorders in physical therapists: a prospective cohort study with 1-year follow-up. Phys Ther. 2008;88(5):608-19.

15. Cho KH, Beom JW, Lee TS, Lim JH, Lee TH, Yuk JH. Trunk muscles strength as a risk factor for nonspecific low back pain: a pilot study. Ann Rehabil Med. 2014;38(2):234-40.

16. Truszczyńska A, Scherer A, Drzał-Grabiec J. The occurrence of overload at work and musculoskeletal pain in young physiotherapists. Work. 2016;54(3):609-16.

17. Vieira WH, Pedroza EP, Filho RG, Abreu BJ. Prevalência de desconforto musculoesquelético em fisioterapeutas da rede pública hospitalar de Natal/RN. Fisioter Bras. 2015;16(2):107-12.

18. Bleyer FT, Barbosa DG, Andrade RD, Teixeira CS, Felden EP. Sleep and musculoskeletal complaints among elite athletes of Santa Catarina. Rev Dor. 2015;16(2):102-8.

19. Lima Júnior J, Silva T. Análise da sintomatologia de distúrbios osteomusculares em docentes da Universidade de Pernambuco-Campus Petrolina. Rev Dor. 2014;15(4):276-80.

20. Shah S, Dave B. Prevalence of Low Back Pain and Its Associated Risk Factors among Doctors in Surat. Int J Health Sci Res. 2012;2(1):91-102.

21. Raithatha AS, Mishra DG. Musculoskeletal disorders and perceived work demands among female nurses at a tertiary care hospital in India. Int J Chronic Dis. 2016;2016:1-7.

22. Leal GM, Oliveira MR, Bastos VC, Barros MD, Carvalho AG, Campos SL, et al Estudo dos distúrbios musculoesqueléticos em fisioterapeutas: correlaçăo com a rotina do trabalho. MTP \& Rehab J. 2014;12:567-82. 